\title{
Role of Participatory Forest Management in Woody Species Diversity and Forest Conservation: The Case of Gimbo Woreda in Keffa Zone South West Ethiopia
}

\author{
Asrat Alemayhu* Yemiru Tesfaye \\ Southern Agricultural Research Institute, Bonga Agricultural Research Center, Bonga, Ethiopia, and Hawassa \\ University, Wondo Genet College of Forestry and Natural Sciences
}

\begin{abstract}
Participatory forest management was started more than one decade ago in Ethiopia as one of the ways applied to reverse deforestation and depletion of natural resources. However, there are no adequate site specific empirical and quantitative studies on the effectiveness of PFM approaches in conservation of woody species diversity and forest conservation. Therefore, this study was designed to assess the impacts of PFM on woody species diversity in selected forest user groups in Gimbo Woreda, South West Ethiopia. Vegetation data were collected from different PFM user groups and adjacent Non-PFM forest blocks. A total of 63 plots measuring $20 \mathrm{~m} \times 20 \mathrm{~m}$ were employed to collect species composition and structural data. Data for all the sapling and seedlings were also collected within subplots of $5 \mathrm{~m} \mathrm{X} 5 \mathrm{~m}$ and $2 \mathrm{~m} \mathrm{X} 2 \mathrm{~m}$ respectively. Accordingly a total of 73 different woody plant species (72 at PFM and 54 at Non-PFM blocks), representing 64 genera and 35 families were recorded, with 53 species shared. Woody species diversity and evenness were higher in the forest with $\mathrm{PFM}\left(\mathrm{H}^{\prime}=3.04, \mathrm{E}=0.76\right)$ compared to the forest without PFM $\left(\mathrm{H}^{\prime}=2.8, \mathrm{E}=0.70\right)$. The overall average values of sapling and seedling density were also significantly $(\mathrm{p}<.05)$ higher in PFM than Non-PFM forests. However, no significant variations were observed in basal area and dominance of the species between the two forest blocks. Thus it can be concluded that participatory forest management is showing signs of delivering impact in terms of woody species diversity conservation in the study area. However, there is a gap in some of forest user groups in terms of forest protection from an illegal activities. Therefore it is important to conduct further assessments in the remaining forest user group's to have baseline data for further study and performance evaluation over all forests under PFM approaches. Keywords: Forest User Group, Regeneration, Species diversity, Human induced disturbance.
\end{abstract}

DOI: $10.7176 / \mathrm{JEES} / 9-6-01$

Publication date:June $30^{\text {th }} 2019$

\section{INTRODUCTION}

Forests have enormous ecological, economical and socio-cultural significances (Ostrom, 1999; Robertson and Lawes, 2005). Forests constitute critical habitat for humanity, providing a range of ecological and environmental services including protection of biodiversity, sequestration of carbon, provisioning of fresh air, renewal of soil fertility, and maintenance of hydrological cycles (FAO, 2012). Rural communities worldwide depends on forests heavily, as these contribute significantly to their livelihoods, providing basic needs, cash resources, and safetynets during times of crisis (Shackleton et al. 2007). Regrettably, despite widespread acknowledgment of the significance of forests, it has been very difficult to tackle deforestation, which continues to represent a major global challenge (Winberg, 2011). Historically, strategies for forest conservation have been dominated by attempts to exclude people from designated forest reserves (Adams and Hulme, 2001). This protectionist approach viewed the development needs of local communities as being in direct conflict with the objectives of biodiversity conservation (Vodouhê et al. 2010). This approach has been pursued as a forest conservation strategy in Sub-Saharan countries (Guthiga, 2008). Similarly, the forest management administration over the last 50 years in Ethiopia has negatively affected the forest resource by restricting local communities' access and user right and Ethiopia continue to face the challenge of how best to manage and conserve their forests (Gebremdhin, 2008).

In response to the problems associated with the fortress approach, since the 1980s a new dialogue has arisen that stresses the need to integrate the views and aspirations of the local people in conservation (Hutton and Williams, 2003). The new approach (PFM) which views them as potential partners in biodiversity conservation (Adams and Hulme, 2001). Integrating the views and needs of local communities in conservation processes are crucial for the effectiveness of participatory forest management (PFM) in improving the forest condition and ensuring the sustainability of the livelihoods of the communities (Stellmacher, 2007; Tsegaye et al. 2009; Yihenew, 2002). Some experiences from around the world show that shifts from state-centered policies toward solutions at the local level, such as PFM, resulted in successful forest conservation and development (Wily, 2002).

However, the PFM institutionalization process and its subsequent performance have proved controversial among different stakeholders. Some claim that a major transformation has taken place consequent to PFM on the management of physical resources, institutional arrangements and livelihoods of resource-dependent communities and decline in the deforestation rate and an increase in forest regeneration (Takahashi and Todo, 2012; Tsegaye et 
al. 2009). While other studies in contrary to this indicated the less emphasis of forest conservation, unsatisfactory seedling establishment and regeneration and lacking follow-up action (Coulibaly-Lingani et al. 2014, Tekalign et al. 2015). Forests under participatory forest management are expanding in coverage in Ethiopia. However, it is still unclear whether the management strategy can really lead to the desired results and it needs to be investigated further (Winberg, 2011). Since, Participatory forestry methods are still in an exploratory phase, it is important to monitor and evaluate in order to transform participation from being an empty promise into being a workable tool.

A number of studies were conducted on different aspects of the impacts of PFM performance. For example, its impacts on forest conservation (Mamo et al. 2016), livelihood and forest status (Tsegaye et al. 2009), species composition and forest structure (Akililu et al. 2016), local communities attitude (Tesfaye, 2017), institutional arrangements versus local practice (Alemayehu et al. 2015), lessons learnt and challenges encountered (Mulugeta and Melaku, 2008) and farmers participation (Girma and Zegeye, 2017) are to name but a few. However, empirical and quantitative evidence remains scarce and are also area limited. Therefore, this paper examined whether PFM management is delivering improved forest condition in terms of woody species diversity, regeneration status, and structure in selected forest user groups in the study area.

\section{Materials and methods}

\subsection{Description of the study area}

The study was carried out in an afro-montane rainforest of Gimbo district (Kaffa Zone, Southwestern Ethiopia). The study area is located at altitudes between 1000 and $3500 \mathrm{~m}$ above sea level and it far $432 \mathrm{~km}$ from Addis Ababa and $705 \mathrm{~km}$ from Hawassa town on the road to Bonga. It found within the geographical location lies within $07^{\circ} 4^{\prime} 00^{\prime \prime}-7^{\circ} 35^{\prime} 00^{\prime \prime} \mathrm{N}$ latitude and $36^{\circ} 1^{\prime} 30^{\prime \prime}-36^{\circ} 31^{\prime} 00^{\prime \prime} \mathrm{E}$ longitude.

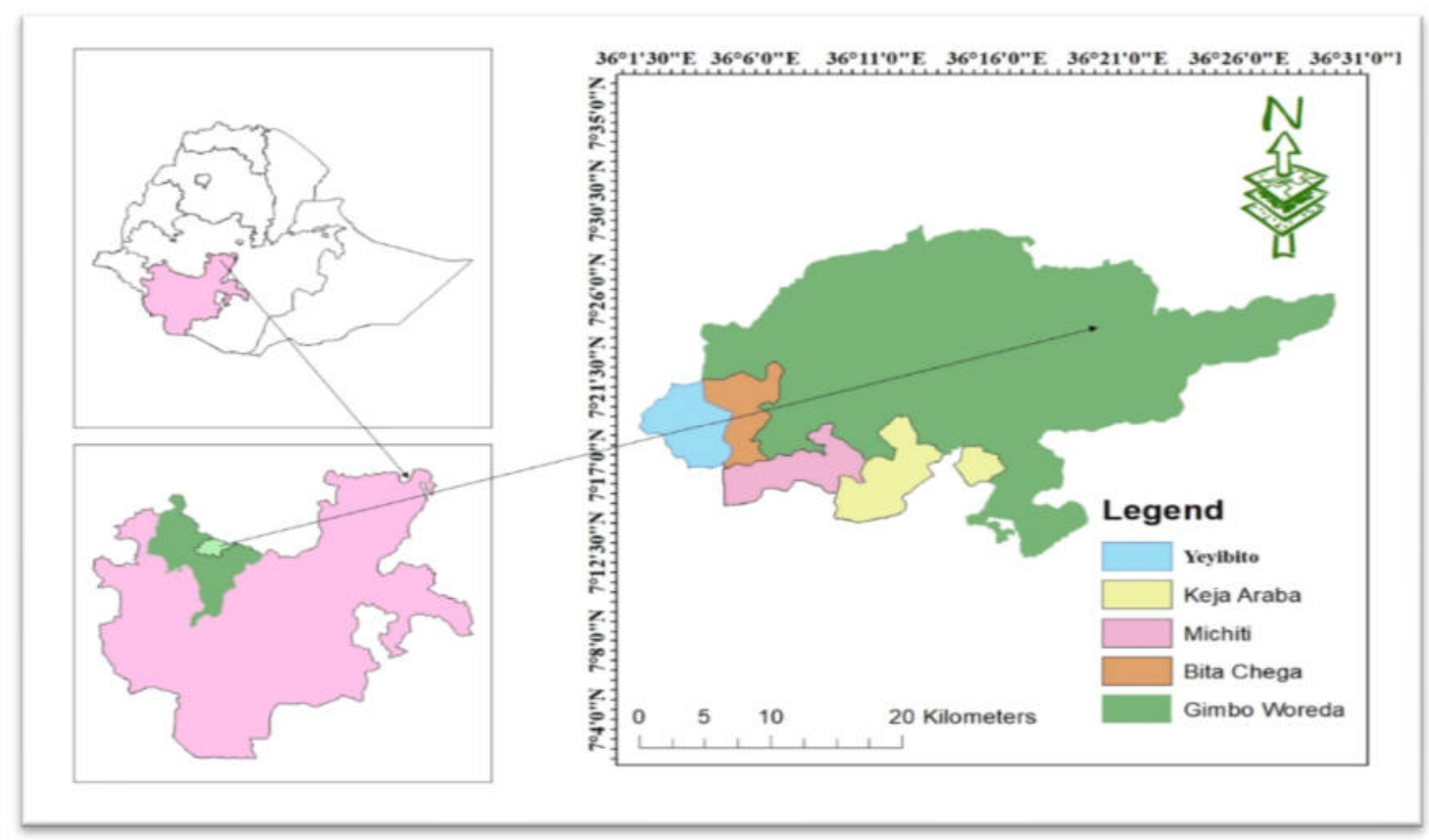

Figure 1: Map of the Study Area

The soils of the area are deep, clay red soils with an agric B-horizon dystric-nitosols. The soils have good agricultural potentialities, good physical properties and uniform profile. They are porous, clay-to-clay loam texture, and have low base saturation with less than $5.5 \mathrm{pH}$ values and well drained (CBFED, 2004).

The mean annual temperature ranging between $15.1^{\circ} \mathrm{C}$ and $22.5^{\circ} \mathrm{C}$ with warmest month January, February and March. The study area receives the highest amount of rainfall in Ethiopia with annual rainfall between 1401$2000 \mathrm{~mm}$. The largest amount of rain occurs between May and September (Ayele, 2011).

The forest in this region fragmented with some undisturbed forest parts and large areas of degraded and disturbed forest. Forest in the study area is classified in the vegetation of Ethiopia referred to as moist evergreen montane forests and located within altitudinal range of 1100-2700 m. above sea level. The forests in this area are normally the richest in species (Friis et al. 1982) and a source of fuel wood, charcoal and timber (Ensermu and Teshome, 2004). The major land cover of Gimbo Woreda is forest and agriculture associated with human settlement. The forests found in the study area are among the remnant forests in Ethiopia where, different kinds of mammals and birds dwell. The main sources of livelihood are forest utilization, livestock rearing and agriculture (Aklilu et al. 2014a). The most income sources of the population are from small-scale agriculture, wild coffee and 
other non-timber forest products (Melaku and Tsegaye, 2005).

\subsection{PFM approach}

In Ethiopia the conventional forest management alienates local communities from participating in forest conservation and protection (Abdurahiman and Tsegaye, 2002), which leads to illegal and unsustainable forest resource utilization. Hence, a resulting paradigm shift is necessary in forest management to involve local community in management of natural resources. Thus Ethiopian government has taken actions to stop forest losses and give the chance for NGOs to participate in SFM, through PFM practices. As a result, a number of NGOs and bilateral programs have launched PFM in the country. In this arrangement the government holds ownership of the forest, while the local communities, organized in FUGs, have use rights (Aklilu et al. 2016). PFM was introduced to Ethiopia in the mid of 1990s, by International NGOs such as the FARM Africa, SOS Sahel, GTZ, and JICA (Temesgen et al. 2007), with thematic area of promoting sustainable management and conservation of forest ecosystems and improving the livelihood of people living in or around. The few PFM pilot activities that started in Ethiopia include projects at Chilimo and Bonga forests by FARM Africa, at Borena by FARM Africa and SOS Sahel, at Adaba Dodolla by GTZ, and Belete Gera forest by JICA (Temesgen et al. 2007). PFM pilot activities in Bonga covered three districts namely, Gimbo, Decha and Gewata. In this PFM processes seven forest user groups were formed in Gimbo district. Out of seven old forest user groups three (Wacha, Agama and Matapa) were selected based on the availability of baseline/reference data for comparison purpose of forest status after the introduction of the PFM approach in the study area particularly in the selected FUGs. And Non-PFM forest patches adjacent to each PFM forest patches were selected to have comparison on the current status of the PFM forest.

\subsection{Sampling design and data collection}

Both primary and secondary data source were used for the study. Primary data was obtained from forest inventory and secondary data from prior baseline data from FARM Africa documents and different literatures. Scholars in the past have used various methods for measuring the condition of a forest, depending upon individual preferences, research objective, and availability of data. Despite these variations, forest ecologists generally agree that both structure and diversity-related variables should be given consideration in order to fully understand the condition of a forest (Gautam, 2007). Accordingly, the study used the following biological variables: basal area of trees $(\geq 10$ $\mathrm{cm} \mathrm{DBH}$ ), density of trees, density of saplings (trees with DBH b/n $1.5 \& 10 \mathrm{~cm}$ ), and density of seedling (trees with height $<1.5 \mathrm{~m}$ ) and richness of woody plant species.

Number of sample plots per patches was calculated using the principles of proportional allocation according to area of each forest patches. The sampling method was based on line transect approach (Marshall et al. 2008) widely suggested to estimate relative density in tropical forests. Sample points along the linear transects were used to collect diversity data and to describe forests structure (Terborgh et al. 2008). In each transect line sample plots were ranged at fixed intervals along linear transects.

Six neighboring forest patches, three with PFM and the other without PFM, but adjacent to each other identified and an inventory was carried out using systematic sampling design to collect vegetation data. A total of 63 square sampling plots, $20 \times 20$ meter were laid at every $200 \mathrm{~m}$ along transect lines and transect apart each other by $500 \mathrm{~m}$ and systematic sampling design was used to select the first transect line and first plot randomly. Accordingly, all woody plant species including trees and shrubs were collected within the main plots, and $5 \mathrm{~m} \mathrm{x} 5$ $\mathrm{m}$ and $2 \mathrm{~m} \times 2 \mathrm{~m}$ sub-plots were laid, four at the corners and one in the middle, for sapling and seedling data collection respectively. Height and diameter at breast height (DBH) of each tree and shrub species with height $>1.5 \mathrm{~m}$ and $\mathrm{DBH}>2.5 \mathrm{~cm}$ were measured. In this study individuals having $<1.5 \mathrm{~m}$ height were counted as seedlings, individuals having $>1.5 \mathrm{~m}$ height and DBH less than $10 \mathrm{~cm}$, were counted as sapling and individuals having DBH $>10 \mathrm{~cm}$, were counted as tree (Ensermu and Teshome, 2004).

\subsection{Data Analysis}

The status of woody species diversity was examined by estimating stem density, importance value index (IVI), forest structure, population structure and diversity pattern (Fisseha, 2008). Stem density was calculated as

Density $(\%)=\frac{\text { Number of individuals of species in all quadrats }}{\text { Total area sampled }} * 100$

Frequency is the proportion of plots in which a species occurred. It is a measure of occurrence of a given species in a given area, which indicates how the species is dispersed and is an ecologically meaningful limit. Frequency of plant species was calculated as;

\section{Frequency $=\frac{\text { Number of quadrats in which a species occur }}{\text { Total number of quadrats thrown in the study sits }} x 100$}

Importance Value Index (IVI) allows a comparison of ecological significance of species in a given forest type and depicts the sociological structure of a population in its totality in the community and it is a good index for summarizing vegetation characteristics and ranking of species (Kendeya, 2003). 
Relative Frequency $=\frac{\text { Frequency of a species }}{\text { Sum of frequency of all species }} * 100$

Relative Density $=\frac{\text { Number of individuals of a species occurred }}{\text { Total number of individuals of all species }} * 100$

Relative Basal Area $=\frac{\text { basal area } / \text { ha of a single species }}{\text { sum of basal area/ha of all species }} * 100$

Therefore, IVI was calculated as:

\section{Importance Value Index $(I V I)=R$. density $+R$. frequency $+R$. basal area}

Regeneration status of sample species in the forest was analyzed by comparing seedling with sapling and sapling with matured trees data according to (Kflay and Kitessa, 2014). To compare woody species diversity of the different forest patches Shannon-wiener diversity and Simpson's diversity indices were computed. The Shannon diversity index was calculated as:

$$
\mathrm{H}^{\prime}=-\sum_{\mathrm{I}=1}^{\mathrm{S}} \text { PI LN PI }
$$

Where $\mathbf{H}^{\prime}$ ' Is Shannon diversity index and $\mathbf{P i}$ is proportion of individuals found in the $\mathbf{i}^{\text {th }}$ Species.

Simpson's diversity index is derived from a probability theory and it is the probability of picking two different species at random (Krebs, 1999). Simpson's diversity (D) was calculated as:

$$
D=1-\sum \mathbf{P}_{\mathbf{i}}^{2}
$$

Where $\mathbf{D}$ is Simpson's diversity index and $\mathbf{P}_{\mathbf{i}}$ is proportion of individuals found in the $\mathbf{i}^{\text {th }}$ species.

Data was analyzed descriptively and using independent t- test. Significant differences in mean values for woody species diversity was tested by least significance difference at $\mathrm{p}<0.05$. All statistical computations was made using SPSS statistical Software.

\section{RESULTS AND DISCUSSION}

\subsection{Woody species composition}

A total of 73 woody species belonging to 64 genera and 35 families were recorded including regeneration and saplings in the different forest patches. Out of the total woody species identified, $72(98.63 \%)$ of them were recorded in the PFM forests, while $54(73.97 \%)$ species in the Non-PFM forests. Only one species $(1.37 \%)$ encountered in the Non-PFM forest was absent from the PFM forest, while eighteen (24.65\%) species found in PFM forest were not encountered in the Non-PFM forest, whereas $53(72.6 \%)$ species were shared by both forest blocks. Out of 35 families, seven were exclusively found in PFM forest and 28 are shared families. Of all the families, Fabaceae, Moraceae, Celastraceae are the most dominant with each contributing 4 species $(5.5 \%)$ next to Rubiaceae with 8 species $(10.95 \%)$. It is also followed by Araliaceae, Dracaenaceae, Oleaceae, Rutaceae families each with 3 species (4.1\%) and Acanthaceae, Boraginaceae, Lamiaceae, Myrtaceae, Sapindaceae, Melianthaceae, families each have 2 species $(2.7 \%)$ are also very important families in terms of species richness. The highest number of families were recorded in PFM forest as compared to adjacent Non PFM forest patches and Rubiaceae was the most dominant family with more numbers of species in all FUGS. Overall analysis of the habit or life forms of species recorded from the different forest patches indicate that the highest proportion (57.5\%) of trees, $26 \%$ tree/shrubs and followed by the shrubs that make up $8.2 \%$ of the total and woody climbers contributes for $8.2 \%$ (Table 1$)$.

Table 1: List of woody species encountered in in the studied forest patches with corresponding family, local names and life form.

\begin{tabular}{|r|l|l|l|l|l|l|}
\hline \multicolumn{1}{|l|}{$\begin{array}{l}\text { No } \\
.\end{array}$} & Scientific Names & Local Name & $\begin{array}{l}\text { Life } \\
\text { form }\end{array}$ & $\begin{array}{l}\text { PF } \\
\text { M }\end{array}$ & $\begin{array}{l}\text { Non- } \\
\text { PFM }\end{array}$ \\
\hline 1 & Acanthus eminens & Acanthaceae & Pheco & S & V & V \\
\hline 2 & Albizia gummifera & Fabaceae & Catoo & $\mathrm{T}$ & $\mathrm{V}$ & $\mathrm{V}$ \\
\hline 3 & Allophylus abyssinicus & Sapindaceae & She'o & $\mathrm{T}$ & $\mathrm{V}$ & $\mathrm{V}$ \\
\hline 4 & Allophylus rubifolius & Sapindaceae & Gurasado & $\mathrm{S} / \mathrm{T}$ & $\mathrm{V}$ & $\mathrm{X}$ \\
\hline 5 & Apodytes dimidiata & Icacinaceae & Wundafo & Tree & $\mathrm{V}$ & $\mathrm{V}$ \\
\hline 6 & Bersama abyssinica & Melianthaceae & Boqqo & Tree & $\mathrm{V}$ & $\mathrm{V}$ \\
\hline 7 & Brucea antidysentricu & Simaroubaceae & Nukasho & $\mathrm{S} / \mathrm{T}$ & $\mathrm{V}$ & $\mathrm{V}$ \\
\hline 8 & Canthium oligocarpum Hiern & Rubiaceae & Xixirabo & $\mathrm{T}$ & $\mathrm{V}$ & $\mathrm{V}$ \\
\hline 9 & Cassipourea malosana & Rhizophoracea & Woralo & $\mathrm{T}$ & $\mathrm{V}$ & $\mathrm{V}$ \\
& & $\mathrm{e}$ & & & \\
\hline
\end{tabular}




\begin{tabular}{|c|c|c|c|c|c|c|}
\hline No & Scientific Names & Family & Local Name & $\begin{array}{l}\text { Life } \\
\text { form }\end{array}$ & $\begin{array}{l}\mathrm{PF} \\
\mathrm{M}\end{array}$ & $\begin{array}{l}\text { Non- } \\
\text { PFM }\end{array}$ \\
\hline 10 & Celtis africana & Ulmaceae & Uffo & $\mathrm{T}$ & $\mathrm{V}$ & $\mathrm{V}$ \\
\hline 11 & Chionanthus mildbraedii & Oleaceae & Shigayo & $\mathrm{S} / \mathrm{T}$ & $\sqrt{ }$ & $\mathrm{V}$ \\
\hline 12 & Clausena anisata & Rutaceae & Emicho & $\mathrm{S} / \mathrm{T}$ & $\mathrm{V}$ & $\mathrm{V}$ \\
\hline 13 & Coffea arabica $L$. & Rubiaceae & Bunno & $\mathrm{S} / \mathrm{T}$ & $\sqrt{ }$ & $\mathrm{V}$ \\
\hline 14 & $\begin{array}{l}\text { Combretum paniculatum } \\
\text { Vent. }\end{array}$ & Combretaceae & $\begin{array}{l}\text { Bagee } \\
\text { Qombo }\end{array}$ & WC & $\sqrt{ }$ & $\mathrm{v}$ \\
\hline 15 & Cordia africana & Boraginaceae & Di'o & $\mathrm{T}$ & $\sqrt{ }$ & $\mathrm{V}$ \\
\hline 16 & Croton macrostachyus & Euphorbiaceae & Waggo & $T$ & $\sqrt{ }$ & $\mathrm{V}$ \\
\hline 17 & Cupressus lusitanica & Cupressaceae & Ciido & $\mathrm{T}$ & $\sqrt{ }$ & $\mathrm{x}$ \\
\hline 18 & Dalbergia lactea Vatka & Fabaceae & Bitbitoo & WC & $\sqrt{ }$ & $\mathrm{V}$ \\
\hline 19 & Dinbollia kilimandscharica & Sapindaceae & Qaqiracho & $T$ & $\sqrt{ }$ & $\mathrm{V}$ \\
\hline 20 & Diospyros abyssinica & Ebenaceae & Kuri & $\mathrm{T}$ & $\sqrt{ }$ & $x$ \\
\hline 21 & Dracaena afromontana & Dracaenaceae & Emo & $\mathrm{S} / \mathrm{T}$ & $\mathrm{V}$ & $\mathrm{V}$ \\
\hline 22 & Dracaena fragrans & Dracaenaceae & Shigiro & $\mathrm{T}$ & $\sqrt{ }$ & $\mathrm{v}$ \\
\hline 23 & Dracaena steudneri & Dracanaceae & Yudo & $\mathrm{T}$ & $\sqrt{ }$ & $x$ \\
\hline 24 & Ehretia cymosa & Boraginaceae & Wogamo & $\mathrm{S} / \mathrm{T}$ & $\sqrt{V}$ & $\mathrm{~V}$ \\
\hline 25 & Ekeberigia capensis & $\begin{array}{l}\text { Rhizophoracea } \\
\text { e }\end{array}$ & Orooro & $T$ & $\sqrt{ }$ & $\mathrm{v}$ \\
\hline 26 & Elaeodendron buchananii & Celastraceae & Washo & $T$ & $\mathrm{~V}$ & $\mathrm{~V}$ \\
\hline 27 & Embelia schimperi & Myrsinac & Dupho & WC & $\sqrt{ }$ & $\mathrm{V}$ \\
\hline 28 & Eucalyptus spp & Myrtaceae & Bahirzaf & $T$ & $\sqrt{ }$ & $\mathrm{x}$ \\
\hline 29 & Euphorbia ampliphylla Pax & Euphorbiaceae & Gacho & $\mathrm{T}$ & $\sqrt{ }$ & $\mathrm{V}$ \\
\hline 30 & Fagaropsis angolensis & Rutaceae & Yayo & $T$ & $\sqrt{ }$ & $\mathrm{V}$ \\
\hline 31 & Ficus ovata & Moraceae & Caroo & $T$ & $\sqrt{V}$ & $\mathrm{~V}$ \\
\hline 32 & Ficus palmata $L$ & Moraceae & Shoto & $T$ & $\sqrt{ }$ & $\mathrm{V}$ \\
\hline 33 & Ficus sur & Moraceae & Capharo & $\mathrm{T}$ & $\sqrt{ }$ & $\mathrm{V}$ \\
\hline 34 & Flacourtia indica & Flacourtiaceae & Humo & $\mathrm{S} / \mathrm{T}$ & $\sqrt{V}$ & $\mathrm{~V}$ \\
\hline 35 & Galiniera saxifraga & Lamiaceae & Dido & $\mathrm{S} / \mathrm{T}$ & $\sqrt{ }$ & $\sqrt{ }$ \\
\hline 36 & Hippocratea africana & Celastraceae & Phi'o & WC & $\sqrt{ }$ & $\sqrt{ }$ \\
\hline 37 & Hippocratea goetzei & Celastraceae & $\begin{array}{l}\text { Qawe } \\
\text { Qombo }\end{array}$ & WC & $\sqrt{ }$ & $\mathrm{x}$ \\
\hline 38 & Ilex mitis & Aquifoliaceae & Qeto & $\mathrm{T}$ & $\sqrt{ }$ & $\mathrm{V}$ \\
\hline 39 & Justicia schimperiana & Acanthaceae & Shashero & $\mathrm{S}$ & $\mathrm{V}$ & $\mathrm{X}$ \\
\hline 40 & Landolphia buchananii & Apocynaceae & Yemo & WC & $\sqrt{ }$ & $\mathrm{V}$ \\
\hline 41 & Lepidotrichilia volkensii & Meliaceae & Shahino & $\mathrm{S} / \mathrm{T}$ & $\sqrt{V}$ & $\mathrm{~V}$ \\
\hline 42 & Macaranga capensis & Euphorbiacee & Shakero & $T$ & $\sqrt{ }$ & $\mathrm{X}$ \\
\hline 43 & Maesa lanceolata & Myrsinaceae & Caggo & $T$ & $\sqrt{ }$ & $x$ \\
\hline 44 & Maytenus undata & Celastraceae & Shiikkoo & $\mathrm{S} / \mathrm{T}$ & $\sqrt{ }$ & $\mathrm{V}$ \\
\hline 45 & Millettia ferruginea & Fabaceae & Bebero & $\mathrm{T}$ & $\sqrt{ }$ & $\mathrm{V}$ \\
\hline 46 & Ocntea kenyensis & Lamiaceae & Najo & $\mathrm{T}$ & $\sqrt{ }$ & $\mathrm{V}$ \\
\hline 47 & Olea welwitschi & Oleaceae & Yaho & $\mathrm{T}$ & $\mathrm{V}$ & $\mathrm{v}$ \\
\hline 48 & Oxyanthus speciosus DC. & Rubiaceae & Ophero & $\mathrm{T}$ & $\sqrt{ }$ & $\mathrm{V}$ \\
\hline 49 & Pavetta oliveriana & Rubiaceae & Tushimo & $\mathrm{S} / \mathrm{T}$ & $\sqrt{V}$ & $x$ \\
\hline 50 & Phoenix reclinata Jacq. & Arecaceae & Yebo & $\mathrm{T}$ & $\mathrm{V}$ & $\mathrm{V}$ \\
\hline 51 & Pittospnrum viridiflarum & Pittosporaceae & Shollo & $\mathrm{S} / \mathrm{T}$ & $\sqrt{ }$ & $\mathrm{V}$ \\
\hline 52 & Podocarpus falcatus & Podocarpaceae & Zigiba & $\mathrm{T}$ & $\mathrm{V}$ & $x$ \\
\hline 53 & Polyscias fulva & Araliaceae & Karasho & $\mathrm{T}$ & $\sqrt{ }$ & $\mathrm{v}$ \\
\hline
\end{tabular}




\begin{tabular}{|l|l|l|l|l|l|l|}
\hline $\begin{array}{l}\text { No } \\
.\end{array}$ & Scientific Names & Family & Local Name & $\begin{array}{l}\text { Life } \\
\text { form }\end{array}$ & $\begin{array}{l}\text { PF } \\
\text { M }\end{array}$ & $\begin{array}{l}\text { Non- } \\
\text { PFM }\end{array}$ \\
\hline 54 & Poureria adolfifreiderici & Sapotaceae & Shao'o & T & V & V \\
\hline 55 & Prunes africana & Rosaceae & Omo & $\mathrm{T}$ & $\mathrm{V}$ & $\mathrm{V}$ \\
\hline 56 & Psychotria orophila & Rubiaceae & Aemato & S/T & $\mathrm{V}$ & $\mathrm{V}$ \\
\hline 57 & Rhamnus prinoides & Rhamnaceae & Gesho & $\mathrm{S} / \mathrm{T}$ & $\mathrm{V}$ & $\mathrm{X}$ \\
\hline 58 & Rothmannia urcelliformis & Rubiaceae & Dibo & $\mathrm{T}$ & $\mathrm{V}$ & $\mathrm{V}$ \\
\hline 59 & Rytigynia neglecta & Rubiaceae & Naxacho & $\mathrm{S} / \mathrm{T}$ & $\mathrm{V}$ & $\mathrm{X}$ \\
\hline 60 & Sapium ellipticum & Euphorbiaceae & Shedo & $\mathrm{T}$ & $\mathrm{V}$ & $\mathrm{V}$ \\
\hline 61 & Schefflera volkensii & Araliaceae & Qero & $\mathrm{T}$ & $\mathrm{X}$ & $\mathrm{V}$ \\
\hline 62 & Schefllera abyssinica & Araliaceae & Butto & $\mathrm{T}$ & $\mathrm{V}$ & $\mathrm{V}$ \\
\hline 63 & Senna didymobotrya & Fabaceae & Shillishillo & $\mathrm{S}$ & $\mathrm{V}$ & $\mathrm{X}$ \\
\hline 64 & Solanecio gigas & Asteraceae & Doo'iroo & $\mathrm{S}$ & $\mathrm{V}$ & $\mathrm{V}$ \\
\hline 65 & Solanecio mannii (hookf.) & Asteraceae & Amittibalo & $\mathrm{S} / \mathrm{T}$ & $\mathrm{V}$ & $\mathrm{V}$ \\
\hline 66 & Syzygium guineense & Myrtaceae & Yino & $\mathrm{T}$ & $\mathrm{V}$ & $\mathrm{V}$ \\
\hline 67 & Trichilia dregeana & Meliaceae & Timo & $\mathrm{T}$ & $\mathrm{V}$ & $\mathrm{X}$ \\
\hline 68 & Trilepisium madagascariense & Moraceae & Gabo & $\mathrm{T}$ & $\mathrm{V}$ & $\mathrm{V}$ \\
\hline 69 & Turraea holstii & Meliaceae & Macce Kucoo & S/T & $\mathrm{V}$ & $\mathrm{X}$ \\
\hline 70 & Vangueria madagascariensis & Rubiaceae & Mesho & $\mathrm{T}$ & $\mathrm{V}$ & $\mathrm{X}$ \\
\hline 71 & Vepris dainellii & Rutaceae & Mengiraxo & S/T & $\mathrm{V}$ & $\mathrm{V}$ \\
\hline 72 & Vepris nobilis (Teclea nobilis) & Rutaceae & Shengaro & $\mathrm{S}$ & $\mathrm{V}$ & $\mathrm{V}$ \\
\hline 73 & Vernonia auriculifera & Asteraceae & Dangirato & $\mathrm{S}$ & $\mathrm{V}$ & $\mathrm{X}$ \\
\hline
\end{tabular}

Note. $(\sqrt{ })$ indicate presence and $(X)$ indicate absence. $T=$ Tree, $S=S h r u b, S / T=S h r u b /$ Tree

\subsection{Woody Species Diversity and Similarity Indices}

Plant species diversity is mostly influenced by human impact and forests with low levels of disturbance has high species diversity compared to disturbed forest (Engida and Teshoma, 2012). Woody plant species diversity index $\left(\mathrm{H}^{\prime}\right)$ for all plant species in PFM and Non-PFM were 3.04 and 2.8, respectively, while the corresponding average values of evenness index (E) were 0.76 and 0.7 in PFM and Non-PFM forests, respectively. Simpson's index for woody plant species in PFM and Non-PFM forest were 0.92 and 0.88 was significantly different, whereas the dominance of species in both blocks was not significantly different (Table 2). This showed that PFM forests had the high number of species diversity and more distribution of plant species than Non-PFM forests. However species diversity, species evenness and Simpson index were slightly higher in adjacent Non-PFM forest than in Matapa PFM forest. And this may be due to the influence of human disturbance factors resulted from dependency of group members on forest and forest products. Therefore it's important to note that group formation alone without monitoring and evaluation of the performance of FUGs is not the success by itself.

Table 2: Species Diversity, Species Richness and Evenness of D/t Forest Patches.

\begin{tabular}{|c|c|c|c|c|c|c|c|c|c|}
\hline \multirow[t]{2}{*}{ Characteristics } & \multicolumn{2}{|c|}{ Wacha } & \multicolumn{2}{|c|}{ Matapa } & \multicolumn{2}{|c|}{ Agama } & \multirow{2}{*}{$\begin{array}{l}\text { Avg. } \\
\text { PFM }\end{array}$} & \multirow{2}{*}{$\begin{array}{l}\text { Avg. } \\
\text { Non } \\
\text { PFM }\end{array}$} & \multirow{2}{*}{$\begin{array}{l}\text { P- } \\
\text { value }\end{array}$} \\
\hline & PFM & $\begin{array}{l}\text { Non } \\
\text { PFM }\end{array}$ & PFM & $\begin{array}{l}\text { Non } \\
\text { PFM }\end{array}$ & PFM & $\begin{array}{l}\text { Non } \\
\text { PFM }\end{array}$ & & & \\
\hline $\begin{array}{ll}\text { Species diversity } \\
\left(\mathrm{H}^{\prime}\right)\end{array}$ & 3.08 & 2.65 & 2.78 & 2.84 & 3.26 & 2.91 & 3.04 & 2.8 & \\
\hline Species richness (S) & 54 & 52 & 55 & 54 & 58 & 55 & $56^{b}$ & $54.00^{\mathrm{a}}$ & $0.010^{*}$ \\
\hline Evenness (E) & 0.77 & 0.67 & 0.69 & 0.73 & 0.82 & 0.7 & $0.76^{b}$ & $0.70^{\mathrm{a}}$ & $0.027^{*}$ \\
\hline Simpson index & 0.93 & 0.86 & 0.87 & 0.88 & 0.94 & 0.9 & $0.92^{b}$ & $0.88^{\mathrm{a}}$ & $0.013^{*}$ \\
\hline Dominance & 0.07 & 0.09 & 0.13 & 0.16 & 0.06 & 0.11 & $0.08^{\mathrm{a}}$ & $0.12^{\mathrm{a}}$ & 0.11 \\
\hline Basal area $\left(\mathrm{m}^{2} / \mathrm{ha}\right)$ & 22.65 & 27.6 & 37.6 & 38.2 & 26.59 & 25.57 & $28.9^{\mathrm{a}}$ & $30.46^{\mathrm{a}}$ & 0.07 \\
\hline Seedling (ha-) & 59062 & 48266 & 67292 & 56319 & 71458 & 61356 & $65937^{b}$ & $5_{5313}{ }^{a}$ & $0.00 *$ \\
\hline Sapling (ha') & 18100 & 17902 & 16100 & 16859 & 26633 & 21939 & $20278^{b}$ & $18900^{\mathrm{a}}$ & $0.003 *$ \\
\hline Matured Tree (ha') & 604 & 418 & 335 & 391 & 613 & 431 & $517^{b}$ & $413^{a}$ & $0.006^{*}$ \\
\hline
\end{tabular}

*significant at $\mathrm{p}<0.05$ and Means with the same letters across row are not significantly different $(\mathrm{P}>0.05)$ with respect to forest management approaches. 


\subsection{Regeneration Status}

Regeneration is an indication of forest condition improvement (Yadav et al. 2002). Regeneration of the forest under PFM management has exhibited advanced number of seedling and sapling than compared to the forest under Non-PFM. The average number of seedling and sapling recorded in three PFM forests was 65937 and 20278 per hectare, respectively. Whereas in Non-PFM forests 55313 and 18900 seedling and saplings per hectares, respectively. The difference in the density of sapling and seedling were significant at $\mathrm{p}<.05$ (Table 2 ). Similarly, forests under PFM management has a high number of average matured tree density $(517.3 / \mathrm{ha})$ than Non-PFM forests (413/ha).

Regeneration status of the forest under different forest user group exhibited different performance. The maximum number of seedling, sapling and matured trees were recorded in Agama PFM forest over the rest FUGs. Similarly in all FUGs the total number of seedling per hectare were higher as compared to respective adjacent Non-PFM forest patches. Wacha and Agama PFM exhibited more density of sapling and matured tree as compared to adjacent forest without PFM, Whereas Matapa PFM revealed low density of sapling and matured tree per hectare as compared to forest under Non-PFM. This may be due to human induced disturbance. Regeneration of the matured woody species as seedling ranges from 60\% at Agama PFM to 52\% at Matapa PFM forest patches and as saplings range from $80 \%$ at Wacha PFM to $57 \%$ at Matapa PFM. In both seedling and sapling cases, the representation of matured trees was less in Matapa PFM forest patches even from Non-PFM forest patches.

Comparison result of the current regeneration status of the forest patches with the reference data showed that the regeneration of forest under PFM has improved, i.e. the number of seedling and sapling exhibited an increment in all forests under different forest user groups (Table 3) and the increment was significant at $\mathrm{p}<0.05$.

Table 3: Density of seedling and saplings in different PFM sites in 2004 \& 2017

\begin{tabular}{|lllllllll|}
\hline Characteristics & \multicolumn{2}{c}{ Wacha } & \multicolumn{2}{c}{ Matapa } & \multicolumn{2}{c|}{ Agama } & F-value & P- \\
\hline Year & 2004 & 2017 & 2004 & 2017 & 2004 & 2017 & & value \\
\cline { 1 - 7 } Density of seedling & 3527.8 & 59062 & 6155.6 & 67292 & 391.6 & 71458 & 244.153 & 0.00 \\
\hline Density of sapling & 1147.2 & 18100 & 2663.8 & 16100 & 326.2 & 26633 & 32.758 & 0.005 \\
\hline
\end{tabular}

\subsection{Forest Structure}

\subsubsection{Diameter Class Distribution}

The forest structure in both PFM and free access forests showed an inverted "J" shape for tree diameter distribution. In both forest patches, small-sized individuals are present in a large amount (Figure 2). But relatively PFM forest block has more individuals across different diameter classes compared to Non-PFM forest patches. The distribution of tree/shrub species in different DBH size classes indicates that $610(91 \%)$ of individuals was found in DBH class 2.5-10 cm forest with PFM and $568(92.1 \%)$ for forest in Non-PFM. The density of individuals of woody plant species with DBH $10.1-30 \mathrm{~cm}$ was found to be $78(5.8 \%)$ for forest with PFM and $58(4.7 \%)$ for forest without PFM and only $15(1.1 \%)$ of individuals has found with DBH greater than 70cm in PFM forest than $6(0.5 \%)$ in Non-PFM forests. Even so the difference is not significant, more number of individuals were found in the higher DBH class in PFM forest than compared to Non-PFM forests. This indicates that the forest structure of the PFM forest is more stable in average than Non-PFM forest patches.

\subsubsection{Density, Basal area and Frequency}

Density of a given species is expressed as number of stems per hectare. All most similar average stem density was recorded in both PFM and Non-PFM forest patches each has recorded 358 stems per hectare. Coffea arabica L (4400 stems/ha), Maytenus undata (3250 stems/ha), Chionanthus mildbraedii (2187 stems/ha) and Rothmannia urcelliformis (1616 stems/ha) are the top densely populated woody species in PFM forest patches, whereas, Coffea arabica L (6833 stems/ha), Maytenus undata (1520 stems/ha) and Dracaena afromontana (1516 stems/ha) are densely populated woody species in Non-PFM forest patches. Based on their density the most and least tree species under different forest patches were indicated under table 4.

The average basal area of all woody species in forest with PFM was about $28.9 \mathrm{~m}^{2} \mathrm{ha}^{-1}$ while in the NonPFM forest was about $30.46 \mathrm{~m}^{2} \mathrm{ha}^{-1}$, but the variation was not significant $(p>.05)$ (Table 2). The highest proportion of basal area in forest with PFM was contributed by Schefflera abyssinica (36\%), Olea welwitschi (39.9\%), Sapim ellipticum (14.3\%), Phoenix reclinata (9.39\%) and Coffea arabica L. (10.3\%). In the Non-PFM forest the highest basal area was contributed by Coffea arabica L. (50.56\%), followed by Olea welwitschi (18.08\%), Syzygium guineense (3.6\%), Schefflera abyssinica $(2.85 \%)$ and Maytenus undata $(2.7 \%)$. The lower basal area observed in the PFM forest may be resulted from very low stocking among the mid-size classes despite the presence of some very large trees. However the difference was not statistically significant $(p>.05)$. This result was in line with Solomon et al. (2016)'s study which reported not significant impact of PFM on basal area. Similarly Tsegaye et al. (2009) also reported more basal area in Non-PFM (19.6 $\left.\mathrm{m}^{2} / \mathrm{ha}\right)$ forest than PFM (17.4 $\mathrm{m}^{2} / \mathrm{ha}$ ) forest patches. 
Frequency is the number of quadrats in which a given species occurred in the study area. Frequency is the indication of homogeneity and heterogeneity of given vegetation in which the higher number of species in higher frequency classes and low number of species in lower frequency classes show similar species composition while large number of species in lower frequency classes and small number of species in higher frequency classes indicates higher heterogeneity (Lamprecht, 1989). Maytenus undata, Phoenix reclinata Jacq., Olea welwitschi, Lepidotrichilia volkensii and Coffea arabica L. are the most frequently observed species in PFM forest, while, Olea welwitschi, Coffea arabica L., Dracaena afromontana and Maytenus undata are the top frequently observed species in Non-PFM forest patches.

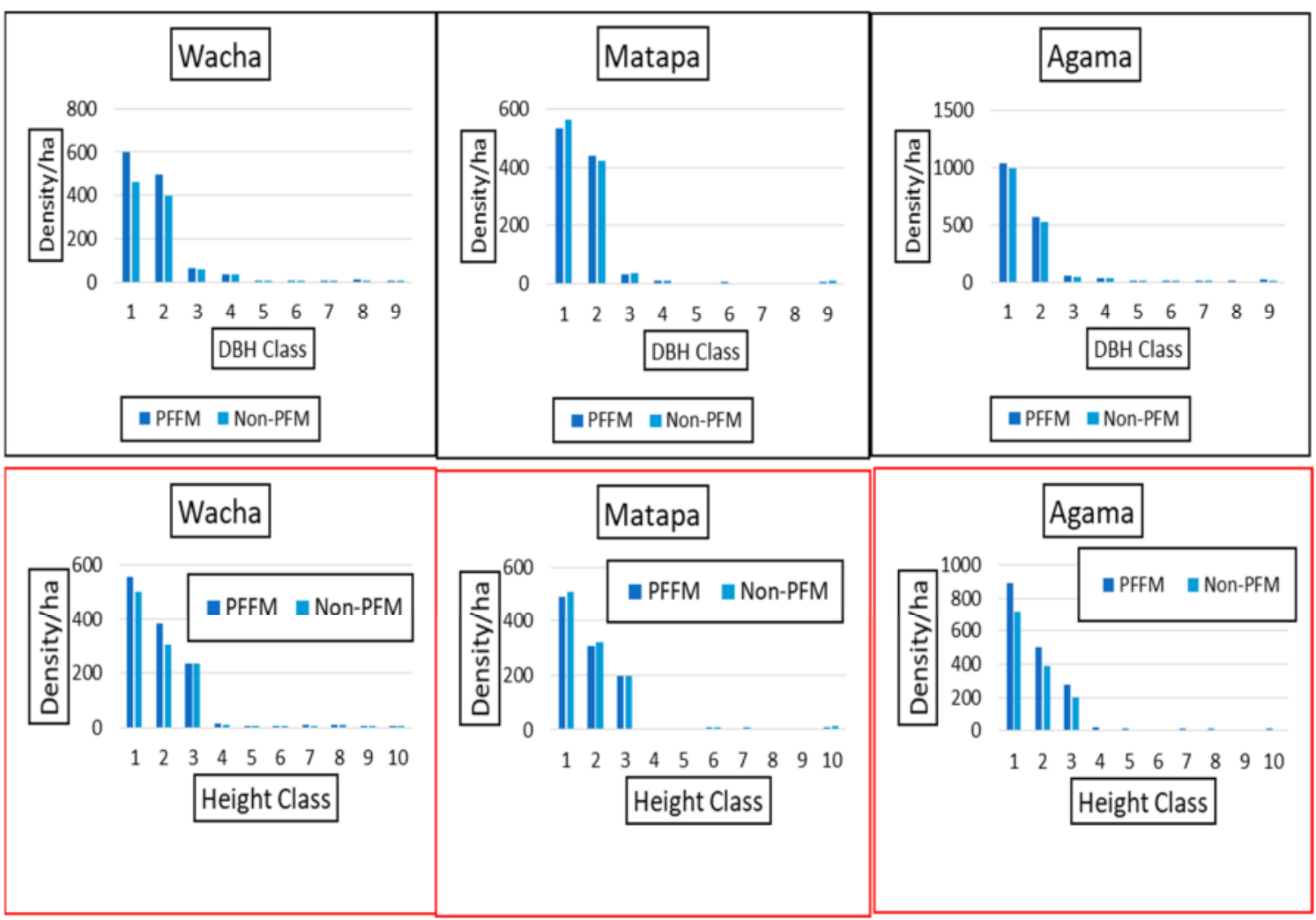

Figure 2: DBH Class Distribution of Woody Species in Different Forest Patches

(DBH Class: $1=2.5-5 \mathrm{~cm}, 2=5.01-10 \mathrm{~cm}, 3=10.01-20 \mathrm{~cm}, 4=20.01-30 \mathrm{~cm}, 5=30.01-40 \mathrm{~cm}, 6=40.01-50 \mathrm{~cm}, 7=50.01-$ $60 \mathrm{~cm}, 8=60.01-70 \mathrm{~cm}, 9=>70 \mathrm{~cm}$ ) and (Height class: $1=<5 \mathrm{~m}, 2=5.0-10 \mathrm{~m}, 3=10.0-15 \mathrm{~m}, 4=15-20 \mathrm{~m}, 5=20-25 \mathrm{~m}$, $6=25-30 \mathrm{~m}, 7=30-35 \mathrm{~m}, 8=35-40 \mathrm{~m}, 9=40-45 \mathrm{~m}, 10=>45 \mathrm{~m})$

Table 4: Five most and least tree species based on their density.

\begin{tabular}{|c|c|c|c|c|c|c|}
\hline & \multicolumn{2}{|c|}{ Wacha } & \multicolumn{2}{|c|}{ Matapa } & \multicolumn{2}{|c|}{ Agama } \\
\hline & PFM & Non-PFM & PFM & Non-PFM & PFM & Non-PFM \\
\hline \multirow{5}{*}{$\sum_{\bar{g}}^{\bar{g}}$} & $\begin{array}{l}\text { Maytenus } \\
\text { undata }\end{array}$ & $\begin{array}{l}\text { Scheflera } \\
\text { abyssinica }\end{array}$ & $\begin{array}{l}\text { Coffea arabica } \\
\text { L. }\end{array}$ & $\begin{array}{l}\text { Maytenus } \\
\text { undata }\end{array}$ & $\begin{array}{l}\text { Coffea arabica } \\
\text { L. }\end{array}$ & $\begin{array}{l}\text { Coffea arabica } \\
\text { L. }\end{array}$ \\
\hline & $\begin{array}{l}\text { Coffea arabica } \\
\text { L. }\end{array}$ & $\begin{array}{l}\text { Croton } \\
\text { macrostachyu } \\
\text { s }\end{array}$ & $\begin{array}{l}\text { Rothmannia } \\
\text { urcelliformis }\end{array}$ & $\begin{array}{l}\text { Chionanthus } \\
\text { mildbraedii }\end{array}$ & $\begin{array}{l}\text { Maytenus } \\
\text { undata }\end{array}$ & $\begin{array}{l}\text { Maytenus } \\
\text { undata }\end{array}$ \\
\hline & $\begin{array}{l}\text { Clausena } \\
\text { anisata }\end{array}$ & Ficus ovata & $\begin{array}{l}\text { Ocntea } \\
\text { kenyensis }\end{array}$ & $\begin{array}{l}\text { Dracaena } \\
\text { afromontana }\end{array}$ & $\begin{array}{l}\text { Chionanthus } \\
\text { mildbraedii }\end{array}$ & $\begin{array}{l}\text { Dracaena } \\
\text { afromontana }\end{array}$ \\
\hline & $\begin{array}{l}\text { Lepidotrichilia } \\
\text { volkensii }\end{array}$ & $\begin{array}{l}\text { Olea } \\
\text { welwitschi }\end{array}$ & $\begin{array}{l}\text { Chionanthus } \\
\text { mildbraedii }\end{array}$ & Vepris dainellii & $\begin{array}{l}\text { Dracaena } \\
\text { afromontana }\end{array}$ & $\begin{array}{l}\text { Rothmannia } \\
\text { urcelliformis }\end{array}$ \\
\hline & $\begin{array}{l}\text { Chionanthus } \\
\text { mildbraedii }\end{array}$ & $\begin{array}{l}\text { Syzygium } \\
\text { guineense }\end{array}$ & Vepris dainellii & $\begin{array}{l}\text { Croton } \\
\text { macrostachyus }\end{array}$ & $\begin{array}{l}\text { Rothmannia } \\
\text { urcelliformis }\end{array}$ & $\begin{array}{l}\text { Lepidotrichilia } \\
\text { volkensii }\end{array}$ \\
\hline \multirow{2}{*}{ త్ } & $\begin{array}{l}\text { Allophylus } \\
\text { abyssinicus }\end{array}$ & $\begin{array}{l}\text { Cassipourea } \\
\text { malosana }\end{array}$ & $\begin{array}{l}\text { Poureria } \\
\text { adolfifreiderici }\end{array}$ & Polyscias fulva & $\begin{array}{l}\text { Poureria } \\
\text { adolfifreiderici }\end{array}$ & Ehretia cymosa \\
\hline & Celtis africana & Polyscias & Ilex mitis & Prunes & Ficus palmata & Allophylus \\
\hline
\end{tabular}




\begin{tabular}{|c|c|c|c|c|c|}
\hline & fulva & & africana & $L$ & abyssinicus \\
\hline Ficus sur & Ilex mitis & $\begin{array}{l}\text { Sapium } \\
\text { ellipticum }\end{array}$ & $\begin{array}{l}\text { Ehretia } \\
\text { cymosa }\end{array}$ & $\begin{array}{l}\text { Cassipourea } \\
\text { malosana }\end{array}$ & $\begin{array}{l}\text { Ficus palmata } \\
\text { L }\end{array}$ \\
\hline $\begin{array}{l}\text { Apodytes } \\
\text { dimidiata }\end{array}$ & $\begin{array}{l}\text { Cordia } \\
\text { africana }\end{array}$ & $\begin{array}{l}\text { Croton } \\
\text { macrostachyus }\end{array}$ & Ficus sur & Polyscias fulva & Celtis africana \\
\hline $\begin{array}{l}\text { Poureria } \\
\text { adolfifreiderici }\end{array}$ & $\begin{array}{l}\text { Fagaropsis } \\
\text { angolensis }\end{array}$ & Ehretia cymosa & $\begin{array}{l}\text { Poureria } \\
\text { adolfifreiderici }\end{array}$ & Ilex mitis & $\begin{array}{l}\text { Apodytes } \\
\text { dimidiata }\end{array}$ \\
\hline
\end{tabular}

3.4.3. Importance value index (IVI)

As described by Kent and Coker (1992), importance value index (IVI) is a good index for summarizing vegetation characteristics, ranking species, management and conservation practices. It is also useful to compare the ecological significance of species (Lamprecht, 1989). Scheflera abyssinica (39.18\%), Olea welwitschi (78.04\%), Coffea arabica L. (42.67\%), Maytenus undata (24.07\%), Phoenix reclinata (19.95\%) and Trilepisium madagascariense $(12.3 \%)$ are the highest IVI value recorded species in PFM forest. Similarly, Coffea arabica L. (83.41\%), Phoenix reclinata $(21.51 \%)$, Dracaena afromontana $(13.63 \%)$ and Maytenus undata $(12.09 \%)$ were also the most dominant species in Non-PFM forest patches.

Table 5: The most and least five plant species based on their IVI values

\begin{tabular}{|c|c|c|c|c|c|}
\hline Patches & No. & Most & IVI & Least & IVI \\
\hline \multirow{10}{*}{ 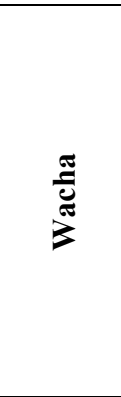 } & \multirow{5}{*}{$\sum_{\substack{\mid=1 \\
L}}$} & Scheflera abyssinica & 39.18 & Brucea antidysentricu & 0.6 \\
\hline & & Maytenus undata & 24.07 & Prunes africana & 0.6 \\
\hline & & Phoenix reclinata & 19.95 & Diospyros abyssinica & 0.6 \\
\hline & & Coffea arabica $L$. & 13.08 & Apodytes dimidiata & 0.6 \\
\hline & & Sapium ellipticum & 17.73 & Embelia schimperi & 0.7 \\
\hline & \multirow{5}{*}{ 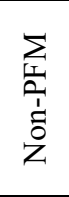 } & Coffea arabica $L$. & 91.75 & Combretum paniculatum & 1.11 \\
\hline & & Olea welwitschi & 23.66 & Cordia africana & 1.11 \\
\hline & & Dracaena afromontana & 14.99 & Euphorbia ampliphylla & 1.11 \\
\hline & & Maytenus undata & 13.30 & Schefflera volkensii & 1.11 \\
\hline & & Lepidotrichilia volkensii & 12.41 & Cassipourea malosana & 1.05 \\
\hline \multirow{10}{*}{ 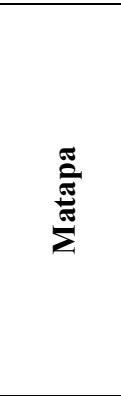 } & \multirow{5}{*}{$\sum_{\substack{L \\
L}}$} & Olea welwitschi & 78.04 & Prunes africana & 0.7 \\
\hline & & Coffea arabica $L$ & 42.67 & Allophylus rubifolius & 0.7 \\
\hline & & Trilepisium madagascariense & 12.3 & Brucea antidysentricu & 0.7 \\
\hline & & Rothmannia urcelliformis & 11.75 & Rhamnus prinoides & 0.7 \\
\hline & & Ocntea kenyensis & 9.18 & Poureria adolfifreiderici & 0.8 \\
\hline & \multirow{5}{*}{ 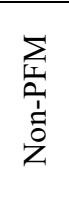 } & Maytenus undata & 87.58 & Combretum paniculatum & 1.06 \\
\hline & & Vepris dainellii & 22.59 & Cordia africana & 1.06 \\
\hline & & Dracaena afromontana & 14.31 & Euphorbia ampliphylla & 1.06 \\
\hline & & Coffea arabica $L$ & 12.69 & Schefflera volkensii & 1.06 \\
\hline & & Lepidotrichilia volkensii & 11.84 & Cassipourea malosana & 1.00 \\
\hline \multirow{10}{*}{ 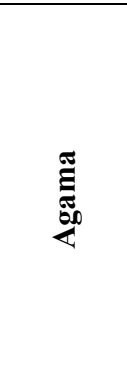 } & \multirow{5}{*}{$\sum_{\substack{\mid=1 \\
\Sigma}}$} & Olea welwitschi & 43.71 & Cassipourea malosana & 0.5 \\
\hline & & Coffea arabica $L$. & 23.11 & Cordia africana & 0.5 \\
\hline & & Phoenix reclinata & 19.53 & Euphorbia ampliphylla & 0.5 \\
\hline & & Maytenus undata & 14.34 & Ficus palmata $L$ & 0.5 \\
\hline & & Scheflera abyssinica & 12.13 & Maesa lanceolata & 0.5 \\
\hline & \multirow{5}{*}{ 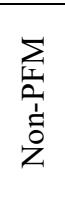 } & Coffea arabica $L$. & 83.41 & Cassipourea malosana & 1 \\
\hline & & Olea welwitschi & 21.51 & Cordia africana & 1 \\
\hline & & Dracaena afromontana & 13.63 & Euphorbia ampliphylla & 1 \\
\hline & & Maytenus undata & 12.09 & Schefflera volkensii & 1 \\
\hline & & Lepidotrichilia volkensii & 11.28 & Combretum paniculatum & 1 \\
\hline
\end{tabular}

\section{CONCLUSION AND RECOMMENDATIONS}

\subsection{Conclusion}

The research findings revealed that the intervention of PFM program was associated with substantial improvements in woody species diversity and forest conditions. This study founded that there is a differences in species composition, diversity, and vegetation structure between the two forest management regimes. More species diversity and richness in Agama and Wacha PFM forest indicated that the PFM approach contributed better forest management than the Non-PFM managed forests. And the lower value of species diversity and species evenness were recorded in Matapa as compared to adjacent Non-PFM forest. The regeneration of woody species was better 
in PFM forest compared with adjacent Non-PFM forest. The density of seedling, sapling and matured trees were recorded higher in Agama and Wacha PFM forest as compared to adjacent Non-PFM forests. The density of seedling in Matapa PFM was recorded higher than to the adjacent Non-PFM forest, but lower density of sapling and matured tree as compared to adjacent Non-PFM forest. Wacha and Matapa PFM forest patches recorded slightly lower value of basal area than to the adjacent Non-PFM forest patches, whereas Agama PFM forest revealed better value of basal area than to the Non-PFM forest patch. There is also a difference in the structure of forest vegetation, especially in the first four diameter size classes between the two forest management units with more density of individuals in PFM forest than Non-PFM forest patches. The present study supports previous arguments that compared to other types of forest management regimes, participatory forest management has a potential to improve forest condition. However, its potential in woody species conservation and forest conservation is not consistent in all forest user groups. Illegal grazing, selective cutting and fuel wood harvesting are observed to be the central part of several disturbances reported to take place in almost all forest patches. Therefore, further to its general positive impacts on forest condition improvement, variation in performance of different forest user groups should be given due attention to make all FUGs competitive in all aspects of participatory forest management objectives. And it is important to protect the remaining Non-PFM forests in the study area from further degradation through scaling up of the program.

\subsection{Recommendations}

From the evaluated impacts of PFM on woody species diversity and forest conservation the following recommendation has been specified for different stakeholders at different level:

Despite the fact that forests under PFM still holds an important proportion of tree species richness, there is a need to prevent further human disturbances within the forest and there is variation in forest conservation within different forest user groups and some of the user groups has low performance than even that of adjacent Non-PFM forests. Therefore it is important to evaluate the internal institutional enforcement on usage of forest products and controlling non-members exploitation. Continuous monitoring and evaluation of the performance of the forest user groups is also an important area to be focused. Tangible benefits what they obtain from being the member of PFM and challenge that hinder from best performance should be examined and further research focused.

\section{Conflict of Interests}

Asrat Alemayhu and Yemiru Tesfaye, the authors of the paper, declare that there is no conflict of interests regarding its publication.

\section{Acknowledgements}

I would like to express my deepest appreciation to all members of the Gimbo district environmental protection and forest office especially Mister Meseret Mulu and his colleague for their unreserved help in sharing basic information and setting free condition for reconnaissance survey and data collection. In addition my thanks to Southern Agricultural Research Institute for its budget allocation, logistic provision and other support with collaboration of Agricultural Growth program two (AGP-II).

\section{Reference}

Abdurahiman K, Tsegaye T. (2002), Granting exclusive user rights to the forest dwellers in the state owned forest: The WAJIB approach in Ethiopia. In Proceedings of the Second International Workshop on Participatory Forestry in Africa, Arusha, Tanzania (pp. 18-22).

Adams W. Hulme D. (2001), Conservation and community. In Hulme, David and Murphree, Marshall (Eds). African Wildlife and Livelihoods. Oxford: James Currey Limited.

Aklilu A, Larsen HO, Mulugeta L. (2014a), Participatory forest management in Ethiopia: learning from pilot projects. Environmental management, 53(4), pp.838-854.

Aklilu Ameha, Henrik Meilby \& Gudina Legese Feyisa, (2016), Impacts of participatory forest management on species composition and forest structure in Ethiopia, International Journal of Biodiversity Science,EcosystemServices\&Management, 12:1-2,139-153, DOI: 10.1080/21513732.2015.1112305

Alemayehu N. Ayana, Nathalie Vandenabeele \& Bas Arts. (2015), Performance of participatory forest management in Ethiopia: institutional arrangement versus local practices. Critical Policy Studies, 11(1), pp.19-38.

Ayele Kebede G. (2011), Delimiting the interface between garden coffee expansion and forest coffee conservation and its implication for protected area management: the case of Kaffa coffee biosphere reserve, university of Klagenfurt Master of Science program management of protected areas (MPAs)

CBFED. (2004), Coordination Bureau of Finance and Economic Development, Regional Atlas, Southern Nations, Nationalities and People's Regional Sate Bureau of Statistics and Population E.M Press, Awassa.

Coulibaly-Lingani, P., Tigabu, M., Savadogo, P. and Odén, P.C. (2014), Participatory forest management in 
Burkina Faso: Members' perception of performance. Journal of forestry research, 25(03), pp.637-646.

E. Winberg, (2011), Participatory forest management in Ethiopia, practices and experiences. Food and Agriculture Organization of the United Nations, Sub regional Office for Eastern Africa.

Ensermu K., Teshome S. (2004), Biodiversity, ecological and regeneration studies in Bonga, Borana and Chilimo forests. In Technical report prepared for Farm Africa-SOS-Sahel. Addis Ababa University, Addis Ababa, Ethiopia.

FAO. (2012), State of the World's Forest; FAO: Rome, Italy.

Fisseha Asmelash. (2008), A Survey of Non-timber Forest Products and their Conservation Status in the Gimbo District, SNNPR, Southwest Ethiopia. MSc Thesis. Addis Ababa University.

Friis, I., Rasmussen, F.N. and Vollesen, K., (1982), Studies in the flora and vegetation of SW Ethiopia. Opera Botanica, 63, pp.1-70.

Gautam Ambika P. (2007), Group size, heterogeneity and collective action outcomes: Evidence from community forestry in Nepal. International Journal of Sustainable Development \& World Ecology, 14(6), pp.574-583.

Gebremdhin, A. (2008), Determinants of Success of Participatory Forest Management (PFM) The case of WAJIB approach in Ethiopia. MSc dissertation submitted to Institutes for Environmental decision

Girma Jatana and Zegeye Paulos. (2017), Farmer's Participation in Participatory Forest Management and Factors Affecting its Performance (The Case of Sodo Zuriya District, Wolaita Zone, Ethiopia. Journal of Economics and Sustainable Development ISSN 2222-1700 (Paper) ISSN 2222-2855, Vol.8, No.9

Guthiga, P.M. (2008), Understanding local communities' perceptions of existing forest management regimes of a Kenyan rainforest. International Journal of Social Forestry, 1(2), pp.145-166.

Hutton, J.M. and Leader-Williams, N. (2003), Sustainable use and incentive-driven conservation: realigning human and conservation interests. Oryx, 37(2), pp.215-226.

Kendeya Gebre Hiwot. (2003), Ecology and management of Boswellia papyrifera (Del.) Hochst. Dry forest in Tigray, North Ethiopia (Doctoral dissertation, submitted for the degree of Doctor of Forest Science in the Faculty of Forest Science and Forest Ecology. George-august-university of Gottingen, Gottingen).

Kflay Gebrehiwot and Kitessa Hundera, (2014), Species composition, Plant Community structure and Natural regeneration status of Belete Moist Evergreen Montane Forest, Oromia Regional state, Southwestern Ethiopia. Momona Ethiopian Journal of Science (MEJS), V 6(1):97-101.

Mammo S., Kebin Z., Wang X., Ahmad B., Shale G., Kebede G., Terfe Y., Liu X. (2016), Does Participatory Forest Management Save the Remnant Forest in Ethiopia? Proceedings of the National Academy of Sciences, India Section B: Biological Sciences, pp.1-14.

Marshall, A.R., Lovett, J.C. and White, P.C. (2008), Selection of line-transect methods for estimating the density of group-living animals: lessons from the primates. American Journal of Primatology, 70(5), pp.452-462.

Melaku B. and Tsegaye B. (2005) Participatory Forest Management in Chilimo and Bonga, Ethiopia, an Evaluation Report, Farm Africa, Addis Ababa.

Mulugeta L and Melaku B. (2008), Participatory forest management best practices, lesson learnt and challenges encountered. The Ethiopian and Tanzanian Experiences FARM-Africa/SOS-Sahel.

Ostrom, E. (1999), "Institutional Analysis, Design Principles, and Threats to Sustainable Community Governance and Management of Commons." In Law and the Governance of Renewable Resources: Studies from Northern Europe and Africa, edited by E. Berge and N. S. Christian, 27-59. Oakland: CS Press.

Robertson, J. and Lawes, M.J. (2005), User perceptions of conservation and participatory management of iGxalingenwa forest, South Africa. Environmental Conservation, 32(1), pp.64-75.

Shackleton, C.M., Shackleton, S.E., Buiten, E. and Bird, N. (2007), The importance of dry woodlands and forests in rural livelihoods and poverty alleviation in South Africa. Forest policy and economics, 9(5), pp.558-577.

Stellmacher, T. (2007), The historical development of local forest governance in Ethiopia: From imperial times to the military regime of the Derg. Africa Spectrum, 42(3), pp.519-530.

Takahashi, R. and Todo, Y. (2012), Impact of community-based forest management on forest protection: evidence from an aid-funded project in Ethiopia. Environmental management, 50(3), pp.396-404.

Tekalign, T., Kaba, U. and Zerihun, K. (2015), Challenges for improving forest conditions and forest based livelihoods through participatory forest management around Bonga, southwestern Ethiopia. International forestry review, 17(3), pp.355-367.

Temesgen, Z., Irwin, B., Jordan, G. and Mckee, J. (2007), Forests, use them or lose them: an argument for promoting forest-based livelihoods rather than alternative non-forest-based livelihoods within PFM programs. Participatory forest management (PFM), Biodiversity and Livelihoods in Africa. Government of Ethiopia in collaboration with other stakeholders, Addis Abeba, Ethiopia, pp.7-17.

Terborgh, J., Nuñez-Iturri, G., Pitman, N.C., Valverde, F.H.C., Alvarez, P., Swamy, V., Pringle, E.G. and Paine, C.E. (2008), Tree recruitment in an empty forest. Ecology, 89(6), pp.1757-1768.

Tesfaye, S.S. (2017), Assessment of Local Community Perception of and Attitude Towards Participatory Forest Management (PFM) System and Its Implications for Sustainability of Forest Condition and Livelihoods: The 
Case of Chilimo-Gaji Forest in Dendi District, West Shewa Zone, Oromia, Ethiopia. J Earth Sci. Clim. Change, 8(382), pp.1-10.

Tsegaye G, Melaku B, Mulugeta L, Habtemariam K. (2009), Participatory forest management and its impacts on livelihoods and forest status: the case of Bonga forest in Ethiopia. Int for Rev. 11:346-358.

Vodouhê, F.G., Coulibaly, O., Adégbidi, A. and Sinsin, B. (2010), Community perception of biodiversity conservation within protected areas in Benin. Forest Policy and Economics, 12(7), pp.505-512.

Wily, L.A. (2002), February. Participatory forest management in Africa: an overview of progress and issues. In second international workshop on participatory forestry in Africa. Defining the way forward: sustainable livelihoods and sustainable forest management through participatory forestry, Arusha, United Republic of Tanzania (pp. 18-22).

Yihenew Zewdie, (2002), Access to forest resources and forest-based livelihoods in highland Kaffa, Ethiopia: a resource management perspective (Doctoral dissertation, University of Huddersfield).

Engida, T.D. and A.J. Teshoma, (2012), The Socio Economic Effects of Community Forest Management: Evidence from Dendi District, Ethiopia. International Affairs and Global Strategy, 4: 15-22.

Yadav, N.P., O.P. Dev, O. Springate-Baginski and J. Soussan, (2003), Forest Management and Utilization under Community Forestry. Journal of Forest and Livelihood, 3: 37-50.

Solomon Tadesse, Muluneh Woldetsadik \& Feyera Senbeta, (2016), Impacts of participatory forest management on forest conditions: Evidences from Gebradima Forest, southwest Ethiopia, Journal of Sustainable Forestry, 35:8, 604-622.

Lamprecht, H. (1989), Silviculture in the Tropics: Tropical Forest Ecosystems and Their Tree Species Possibilities and Methods for Their Long-Term Utilization. Eschborn: Deutshe Gesellschaftfü Technische Zusammenarbeit (GTZ) GmbH.

Kent, M. and Coker, P. (1992), Vegetation Description and Analysis. A practical approach. John Wiley and Sons, New York, 363p

\section{BIOGRAPHICAL SKETCH}

Mister Asrat was born in place name Kaffa zone, in southwest, Ethiopia, in 1982. He attended his primary education (1 - 6) in Sheka zone, southwest Ethiopia. He continued his junior secondary education (7 - 8) at Hasho Primary School; secondary education at Deka Secondary School in Gesha district in Kaffa zone southwest, Ethiopia and the preparatory education at Masha Secondary School in Sheka zone southwest Ethiopia. Then he joined Hawassa University, Wondo Genet College of Forestry and Natural Resources in 2009/10 and obtained his B.Sc. degree in Agroforestry in June 2012. Then he has served at Rural and Agriculture Development office in Sayilem district in Kaffa zone southwest, Ethiopia for two years. And Since 2015 he has been working in southern Agricultural Research Institute in Bonga Agricultural Research Centers as a researcher. In September 2016 he joined School of Graduate Studies of Hawassa University, Wondo Genet College of Forestry and Natural Resources and obtained his M.Sc. degree in Production Forestry in 2018 and currently works in southern Agricultural Research Institute in Bonga Agricultural Research Centers as forestry researcher. 